\title{
Business ecosystems policy in Stra.Tech. Man terms: The case of the Eastern Macedonia and Thrace region
}

\section{Charis Vlados $^{1}$ iD, Dimos Chatzinikolaou ${ }^{2}$}

\begin{abstract}
In the current state of globalization's restructuring, numerous studies are examining policies to strengthen local entrepreneurship and productive systems, in terms of clusters and ecosystems. In this article, we apply and extend the Stra.Tech. Man approach to entrepreneurial dynamics as an alternative base of articulating a business ecosystems development policy. By studying the case of the Eastern Macedonia and Thrace region, one of the less developed regions in Greece, we find that there are possibilities for using the Stra.Tech.Man approach to imprint, record and, by extension, give the possibility of strengthening the strategic, technological, and managerial capacity of the "cells" of specific business ecosystems. In this context, the aim of this study is to outline a new possible direction for policy planning and implementation, in order to expand the local business ecosystems' innovative and competitive competence, especially in the context of a less developed region, by the usage of the ILDI (Institutes of Local Development and Innovation) mechanism. In this direction, we present an "introductory" and qualitative field research we carried out in the region of Eastern Macedonia and Thrace, on a sample of SMEs, in diagnostic terms of Stra.Tech.Man physiology.

Keywords: business ecosystems policy, clusters, Stra.Tech.Man physiology, small and medium entrepreneurship, Eastern Macedonia and Thrace region, globalization dynamics
\end{abstract}

1 Charis Vlados, Ph.D. Scholar, Lecturer, Department of Economics, Democritus University of Thrace, Panepistimioupoli Komotini, 69100, tel. +302531039824, e-mail: vlad.coop@gmail.com (ORCID ID: 0000-0002-4138-8828). Also, Lecturer, University of Nicosia, School of Business, 46 Makedonitissas Avenue, CY-2417, P.O. Box 24005, CY-1700, Nicosia, Cyprus, tel. +35722841528 .

2 Dimos Chatzinikolaou, Ph.D. candidate, Democritus University of Thrace, Department of Economics, Panepistimioupoli Komotini, 69100, tel. +302531039824, e-mail: dimos.chatzinikolaou@gmail.com (ORCID ID: 0000-0003-2509-6961).

Received 1 November 2018; Revised 10 March 2019, 28 March 2019; Accepted 29 M arch 2019

This is an open access article under the CC BY license (https://creativecommons.org/licenses/by/4.0/legalcode). 


\section{INTRODUCTION}

In the current era of globalization's restructuring (Laudicina \& Peterson, 2016; Vlados, Deniozos, Chatzinikolaou, \& Demertzis, 2018), there is a growing interest in the ways of diagnosing, curing and preventing local and regional underdevelopment and inequalities (Pike, Rodríguez-Pose, \& Tomaney, 2017; Wei, 2015). The structural changes that the various local systems are facing (Haddad, 2018; Isaksen, Tödtling, \& Trippl, 2018; Neffke, Hartog, Boschma, \& Henning, 2018; Uyarra \& Flanagan, 2010) are leading to comparative developmental gaps. In this context, there is an ongoing effort to explain them in terms of entrepreneurial development and innovative capacity (Blackburn, 2016; Golejewska, 2018; Roundy \& Asllani, 2018; Schaltegger, Lüdeke-Freund, \& Hansen, 2016; Storey, 2016) and innovation (Acs, Audretsch, Lehmann, \& Licht, 2017; Etzkowitz \& Zhou, 2017; Frederickson, 2016). This thematic rearrangement of the current research tends to focus on the conditions that create innovation and competitiveness, always based on the particularities of each spatial socioeconomic system.

In this context, the production of knowledge and innovation within business clusters (Gancarczyk \& Bohatkiewicz, 2018; Jensen, Johnson, Lorenz, \& Lundvall, 2016; Piperopoulos, 2016) and regional innovation systems (Asheim, Grillitsch, \& Trippl, 2016; Stuck, Broekel, \& Diez, 2016) reveal the dynamic interdependence of localities in the global system. They also make the small and medium-sized enterprise a crucial development hub of the evolution of the entire regional-national-global system (Bathelt, Malmberg, \& Maskell, 2004).

In this direction, the study of clusters holds a central interpretive position. Cluster theory tries to analyze individual locations in terms of business competitiveness and agglomeration of economic performance. However, the cluster, as a different way of organizing the value chain (Porter, 1998, 2000), although it is part of many policies, cannot capture, as treated by the business ecosystems, the growing competitive complexity in the modern world (Ahokangas, Boter, \& livari, 2018; Kurtz, 2018), the new evolutionary development dynamics (Mack \& Mayer, 2016; Sako, 2018) and the need for interdisciplinary and cross-thematic perception of the relative phenomena (Liguori, Winkler, Hechavarria, \& Lange, 2018).

Although innovation policy in our days uses the cluster logic widely, the concept of the cluster faces criticism, because for some analysts cluster theory seems unable to explain all the factors contributing to the success of specific localities (Kim, 2015; Majava, Rinkinen, \& Harmaakorpi, 2016).

In this context, and in search for articulating more effective local development policies, the aim of this study is to find out if there are any 
possibilities to reposition the applied development policies at local business ecosystems through dynamic business approaches of "biological" order and understanding (Belussi \& Caldari, 2008; Hammerstein \& Hagen, 2005; Kennedy, Miller, \& Niewiarowski, 2018; McMullen, 2018; Meyer \& Davis, 2003; Reeves, Levin, \& Ueda, 2016; Weber \& Hine, 2015; Witt, 2006).

The following steps explain the methodology and structure of the article:

1) We review the business ecosystems and clusters literature and introduce the Stra.Tech.Man triangle approach.

2) We examine different policies for the enhancement of local entrepreneurship capacities in analytical terms of ecosystems and clusters in Europe and introduce an alternative enhancement policy of business ecosystems (the Institutes of Local Development and Innovation).

3) We study the current crisis in Greece and its relation to small and medium-sized enterprises, by examining the case study of a less developed region. We focus, via field research in Eastern Macedonia and Thrace, on a qualitative and non-weighted sample of small and medium-sized enterprises. Specifically, in this direction, we shared questionnaires and obtained data from 45 SMEs operating in the region of Eastern Macedonia and Thrace, irrespective of their sector of activity. After completing the company's contact information and the number of employees, the respondent-a member of the enterprise or the business owner himself or herself-had to answer 24 questions, ranging from "zero to five" on a Likert-type scale (Batterton, Hale, 2017; Harpe, 2015). For each question, the respondent had to mark the score on two levels: today and five years ago, according to his or her personal view. The answer to each question was at the respondent's discretion, without additional help and guidance. Additionally, the respondent could write if he or she wanted a short comment to justify the answer.

4) We analyze the findings of the field research to articulate a first diagnosis of the dynamic physiology of these enterprises in Stra.Tech.Man terms.

5) We arrive at specific conclusions and limitations of the field research.

\section{LITERATURE REVIEW}

\section{The concept of business ecosystems and clusters}

The concept of clusters refers to the local agglomeration of organizations of different nature and purpose, directed towards a particular market, industry, or specific technological sector. The clusters are dynamic units including private enterprises and public institutions, research and funding institutions, and every other institutional construct involved in the development process 
of a locality (Ketels, 2011; Lazzeretti, Sedita, \& Caloffi, 2014; Nathan \& Overman, 2013; Porter \& Ketels, 2009).

The theoretical roots of this analytical class of clusters can be found in the work of Alfred Marshall (1890), although the revival and theoretical reactivation took place only in the 1970 s and 1980 s, mostly by some Italian theorists (Becattini, 1979), in the study and construction of the concept of post-Fordism (Hirsch \& Roth, 1986; Holloway, 1988; Jessop, 1988; Sayer, 1989). Subsequently, the approaches of industrial agglomerations (Storper \& Scott, 1989), of "technopoles" (Scott \& Paul, 1990) and "milieu innovateur" (Camagni, 1995) have highlighted the importance of institutional and nonmarket interactions in the development process and have attached increasing importance to the exploration of innovation dynamics and knowledge (Foray, David, \& Hall, 2009).

With similar conceptual roots, the "ecosystemic" thinking in economic science borrows analytically and metaphorically from evolutionary biology (Ben Letaifa, Gratacap, Isckia, \& Pesqueux, 2013; Korhonen, 2001; Parisot, 2013). It suggests that it is imperative in our days to study the networks of co-evolving and "co-opetitive" participants, who are mutually dependent for their shared efficiency and survival, and which, with their action, lead the socioeconomic system to either its self-renewal or its irrevocable death (Iansiti \& Levien, 2002; Jacobides, Cennamo, \& Gawer, 2018; Moore, 1993; Valkokari \& Ketonen-Oksi, 2018).

However, how does the entrepreneurial ecosystem bibliography perceive the evolutionary dynamics of entrepreneurship? The main feature that we find in a growing body of literature is the effect of this new biological perspective on the formulation of organizational strategy and management (Baldwin, 2012; Bosch \& Olsson, 2018; Iansiti \& Levien, 2004; Isenberg, 2010; Liu \& Rong, 2015; Moore, 2013; Williamson \& Meyer, 2012).

Also, we find some contributions which study the strategic impacts of biological/ecosystem thinking on innovation (Adner \& Kapoor, 2010; Blondel \& Gratacap, 2016; Isckia \& Lescop, 2009) and the diffusion of knowledge within organizations (Valkokari, 2015; Wulf \& Butel, 2017). In addition, the increasing interest in business ecosystems is now reflected in the multitude of studies that attempt to highlight the central body of the literature, its historical formation and evolution (Acs, Stam, Audretsch, \& O'Connor, 2017; Malecki, 2018; Maroufkhani, Wagner, \& Wan Ismail, 2018; Rong, Lin, Li, Burström, Butel, \& Yu, 2018). In this context, we have some useful definitions, which highlight the connection between the biological and economic interpretation in business ecosystems: 
- According to Zahra and Nambisan (2012, p. 222), "As with biological and ecological ecosystems, business ecosystems are susceptible to change, adaptation, and evolution. However, the outcomes of these processes are hard to predict and take time to materialize."

- According to Alvedalen and Boschma (2017, p 889), "The biological/ ecological view on entrepreneurship helps to establish a structure and relationships in the ecosystem. Ecosystems are depicted as geographically bounded areas with mutually dependent components."

- According to Cavallo, Ghezzi, and Balocco (2018, p. 9), "... in the same way as the system of living organisms is considered to be at the heart of the ecosystem in biology, in entrepreneurship, the systemic conditions, such as networks of entrepreneurs, leadership, finance, talent, knowledge and support services, are considered to be at the heart of the entrepreneurial ecosystem, while the framework conditions entail a social context that enables or constrains human interaction."

We understand, therefore, that the ecosystemic thinking links dynamically the different systemic components of socioeconomic environments, where the function of entrepreneurship is crucial. However, it seems that the variety of definitions and the proposed approaches do not result in unanimity on the theoretical basis for the sufficient articulation of developmental policy for the locally based business ecosystems. In this direction, Rinkinen, and Harmaakorpi (2018), by distinguishing the different theoretical orientations between clusters and business ecosystems, observe their different interpretation in terms of policy articulation. The structure of clusters, according to the authors, refers to specific sectors and related businesses, which are characterized by high knowledge specialization, while the role of the public sector is "top-down," intending to expand the local cluster. In contrast, the analytical class of business ecosystems is capable of exploring complementary businesses that create and diffuse knowledge within the "organic" system they create and reproduce. Finally, the role of the public sector in business ecosystem creation is open to questioning, since the authors wonder whether public intervention should have to remove the bottlenecks of evolution as a goal.

\section{Focusing on the cellular component of the business ecosystem: The Stra.Tech.Man physiology of the business}

Therefore, by agreeing that a business ecosystems policy needs to identify the evolutionary action of the agents at a local level, we will try to interpret how the "cellular" level synthesizes the socioeconomic organization structurally; and we will do that by utilizing the Stra.Tech.Man approach (Vlados, 2004, 2005). 
The Stra.Tech.Man approach suggests that the structural and evolutionary center of each business ecosystem is the living enterprise. The Stra.Tech. Man approach draws elements from business biology and the evolutionary theory of systems (Forrester, 1984; Georgescu-Roegen, 1971; Geus, 2002; Gowdy, 1997; Hanusch \& Pyka, 2007; Harlé \& Jouanneault, 1983; Lesourne, 1976; Penrose, 1952; Rothschild, 1990; Schumpeter, 1942) and suggests that a socioeconomic organization/enterprise is a complex evolutionary entity that synthesizes at its core three co-evolving spheres: Strategy (Stra), Technology (Tech), and Management (Man).

In particular, the following three internal questions, continuously and evolutionarily, decide the exceptional, explicit, and consistently advancing dynamic Stra.Tech.Man triangle:

- In terms of Strategy confronting the question: "Where am I, where am I going, how do I get there \& why?"

- In terms of Technology confronting the question: "How do I draw, create, synthesize, spread, and reproduce the means of my work and know-how \& why?"

- In terms of Management confronting the question: "How do I use my available resources \& why?" (see Figure 1 ).

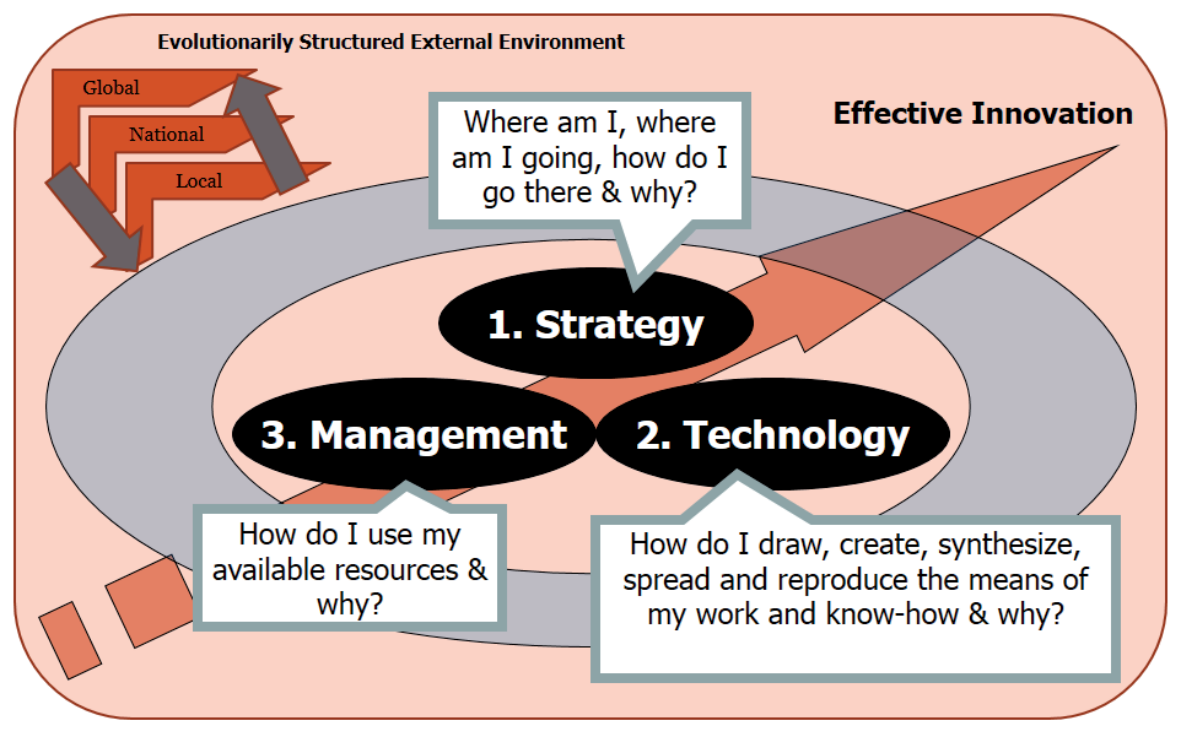

Figure 1. The evolutionary Stra.Tech.Man core of the enterprise.

Source: adapted from Vlados (2004). 
Specifically, the term physiology Stra.Tech.Man (Strategy-TechnologyManagement synthesis) refers to the firm as a living socioeconomic organism. However, the traditional literature perceives relatively superficial the concepts of business culture and vision, the mission, and the business strategy. On the contrary, we argue that all these dimensions have an endogenous, structural, and evolutionary character: we perceive them as organic and physiological processes transformed over time by the evolutionary complexity that does not allow any mechanistic approach. Via this theoretical approach, we can conceive the innovation as an evolutionary synthesis that determines the insertion of every living socioeconomic organization in the spatially unifying dynamics of its external environment (see Figure 2).

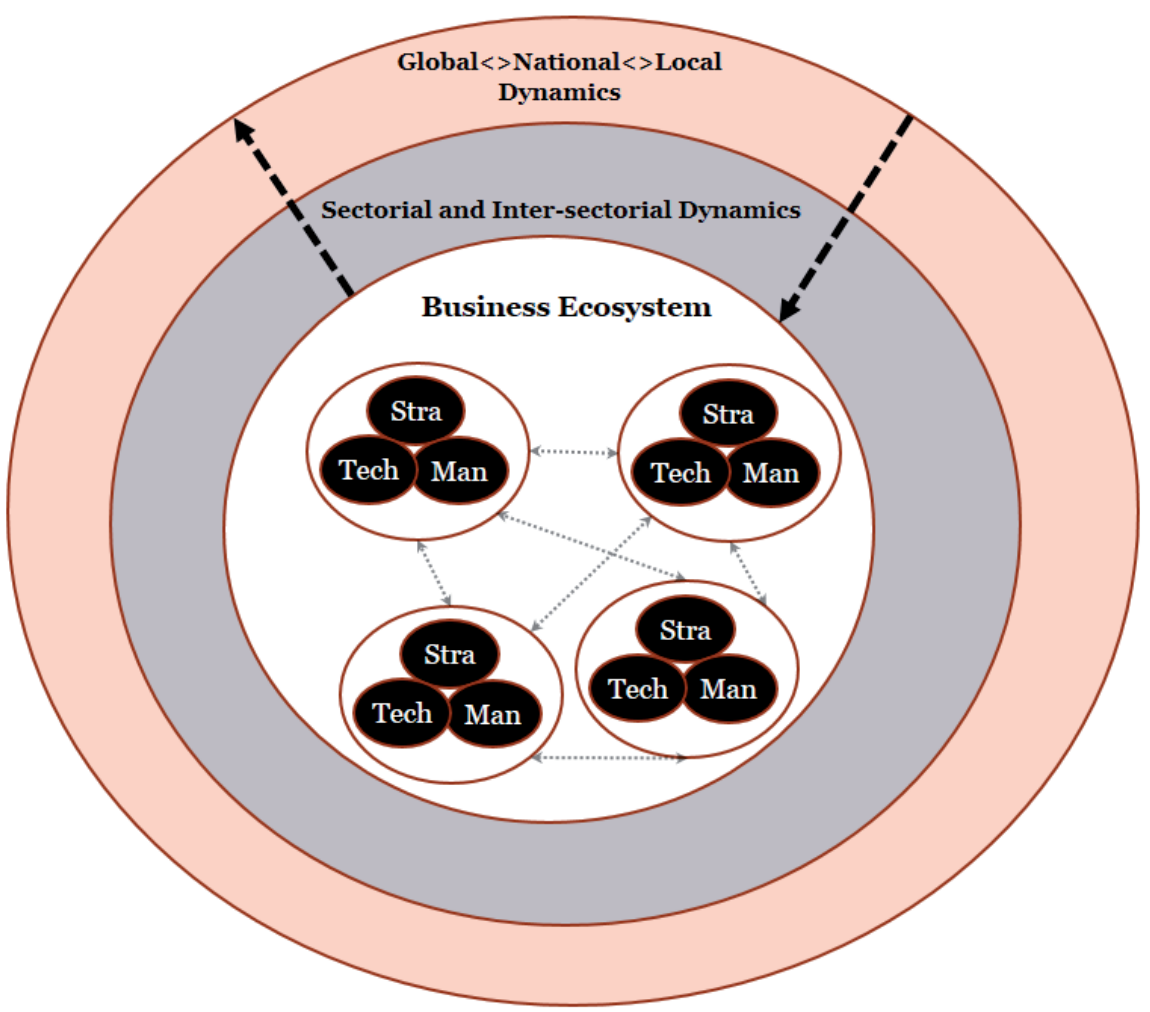

Figure 2. Business ecosystems in inter-sectorial and trans-spatial dynamics

Therefore, we argue that the perception of the firm in Stra.Tech.Man terms can improve our entire understanding of business ecosystems, in critical comprehensions: 
- the firm is the cellular epicenter in the composition of the different business ecosystems;

- the business ecosystems are operating at the same time as producers and receivers of sectorial and inter-sectorial dynamics synthesized at the global level evolutionarily;

- the complete evolutionary procedure unifies and reproduces the partial local, national, and supranational dynamics in the global socioeconomic system.

This approach is founded, indeed, over Alfred Marshall's (1890) theoretical comprehension, in which it became clear that there are no "great leaps in nature" in economic and business evolution (natura non facit saltum). According to Marshall, the Mecca of the economist lies in economic biology rather than in a "conventional" Economics perspective, which perceives the reality usually static and mechanistic. Therefore, by extending this view, we could say that there are no "leaps of physiology" also in Stra.Tech.Man terms and for any organization.

In this direction, we understand that all firms, as "living" socioeconomic organizations, develop complex parallel relationships of competition and cooperation, according to the evolutionary constraints of their internal and external environment. In the current era of globalization's restructuring, a multitude of business ecosystems, with different prospects for evolution, interact with dynamic processes, both in inter-sectorial and inter-spatial level. The spatial socioeconomic systems, hosting and reproducing sectorial and intersectorial dynamics, shape what we call the dynamics of globalization (Carroué, 2002; Delapierre, Moati, \& Mouhoud, 2000; Veltz, 2014) (see Figure 3).

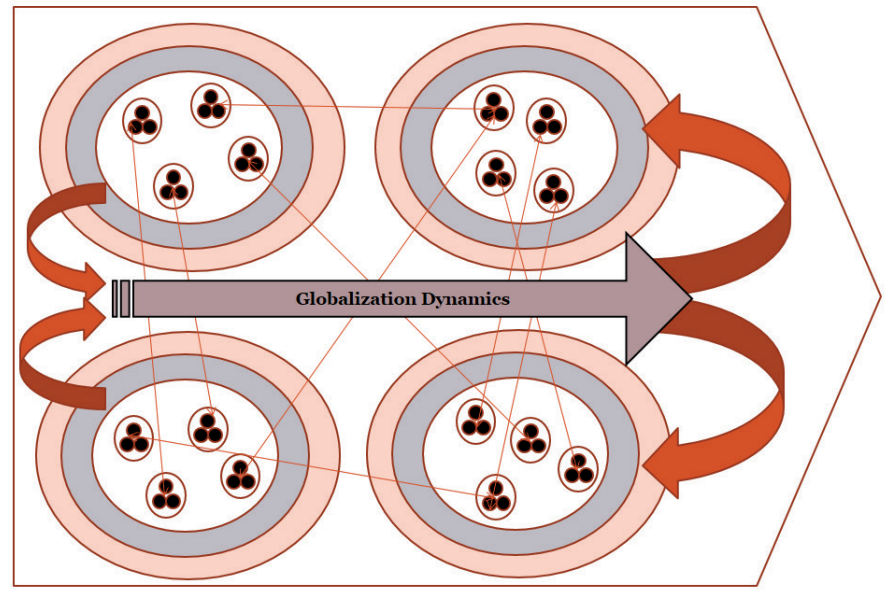

Figure 3. The co-evolution of business ecosystems in global dynamics 


\section{Policies to enhance the local entrepreneurship in terms of ecosystems and clusters in Europe}

How can we strengthen these "living cells" of the local business ecosystem? Initially, there seems no clear conclusion in the study of the effectiveness of business ecosystem policies (Autio \& Levie, 2017). At the same time, it is generally challenging to prove that a business ecosystem has indeed emerged because of focused government interventions (Mason \& Brown, 2014). However, some national clustering policies (Li, 2014; Meier zu Köcker \& Müller, 2015; Pitelis, 2012) follow a cross-sectoral perspective and tend to look like the analytical methodology of business ecosystems. In the memberstates of the European Union, national governments in cooperation with regional or local authorities (Obadić, 2013) mainly implement the policies aimed at cluster development.

In this context, some "in-business" aid interventions can enhance our understanding, through the national studies of the European Restructuring Monitor (Hurley \& Storrie, 2017), and in particular through the Restructuring in SMEs in Europe (Eurofound, 2013). We see that the restructuring of a small and medium-sized enterprise involves the use of external experts and business consultants, which should be approached as early as possible to assist both in the planning and preparation, as well as the management, of restructuring of the "patient-business."

In this context, there is an ongoing dialogue about the role of a modern, local economic policy (Barca, McCann, \& Rodríguez-Pose, 2012; Cooke, Clifton, \& Oleaga, 2005; Rodríguez-Pose, 2013; Scott \& Storper, 2003) which, according to our view, must be able to provide counselling and other support to local businesses.

Therefore, based on the data from the European Restructuring Monitor, we can have a picture of some of the related attempts already implemented:

- In France, the poles of competitiveness (Poles de compétitivité) combine large and small enterprises, research laboratories, specialized suppliers, and education or training providers. The poles of competitiveness in France are either regional or interregional, while generally maintaining a cross-sectoral focus. The "Fonds Unique Interministériel" that is managed by BPIfrance, a state-owned public investment bank founded in 2012, funds these poles. The BPIfrance amalgamated in one place the pre-existing investment funds of France and now supports the innovation and export of French business products by providing financial support and advisory services at every stage of the business development cycle (European Monitoring Centre on Change, 2018b). Overall, today, the competitiveness poles 
include 7,200 businesses employing 760,000 people, with around $73 \%$ being small businesses (European Monitoring Centre on Change, 2018a).

- In Finland, there is also an extensive network of public and private partnerships. Team Finland (European Monitoring Centre on Change, 2018c), for example, is geared towards the internationalization of Finish businesses by providing services such as information, business consulting, training, and funding. Team Finland is, in fact, an umbrella for all the organizations that support the internationalization of Finish enterprises (ministries, regional and local economic development centers, investment funds, and chambers of commerce). This policy creates a one-stop shop that connects national, regional, and local agencies. According to a 2017 survey (Elinkeinoelämän keskusliitto, 2018), about a quarter of the 6,000 internationalized Finnish SMEs have used the services of Team Finland (Akola \& Havupalo, 2013).

- In Norway, there is a state-owned company set up by special legislation, Innovation Norway, which acts as a national development bank and cooperates with all the main actors at the national and local level related to innovation and business development. Innovation Norway enables domestic businesses to access a broad network of business and financial support. It provides consulting services and networking and promotion services. According to Innovation Norway's 2017 annual report (Innovasjon Norge, 2017), Norwegian companies supported by Innovation Norway had $13.7 \%$ higher sales, 5\% higher productivity and $8.7 \%$ more value added than other domestic companies (European Monitoring Centre on Change, 2018d).

- In Ireland, the Local Enterprise Offices (LEOs) are the one-stop shop for anyone looking for information and support to start or develop a business. They provide, among other things, advisory services, direct funding to micro-businesses, education and training, and information about the local business environment (Local Enterprise Offices, 2018). These offices consist of 31 regional support centers, funded by the central government while being supported by local authorities. Local Enterprise Offices are local access points of Enterprise Ireland (EI), the governmental organization responsible for the growth of Irish businesses in global markets (European Monitoring Centre on Change, 2018e, 2018g). Since their establishment in 2014, the Local Enterprise Offices have provided about 32,000 jobs (European Monitoring Centre on Change, 2018f). 


\section{The Institutes of Local Development and Innovation as an alternative policy articulation mechanism to enhance business ecosystems}

Extending the analysis of Vlados et al. (Katimertzopoulos \& Vlados, 2017; Vlados, Deniozos, \& Chatzinikolaou, 2018), a new local development policy for Greece could be the Institutes of Local Development and Innovation (ILDI). It is a one-stop shop service to strengthen the local business ecosystems in the Greek regions (see Figure 4).

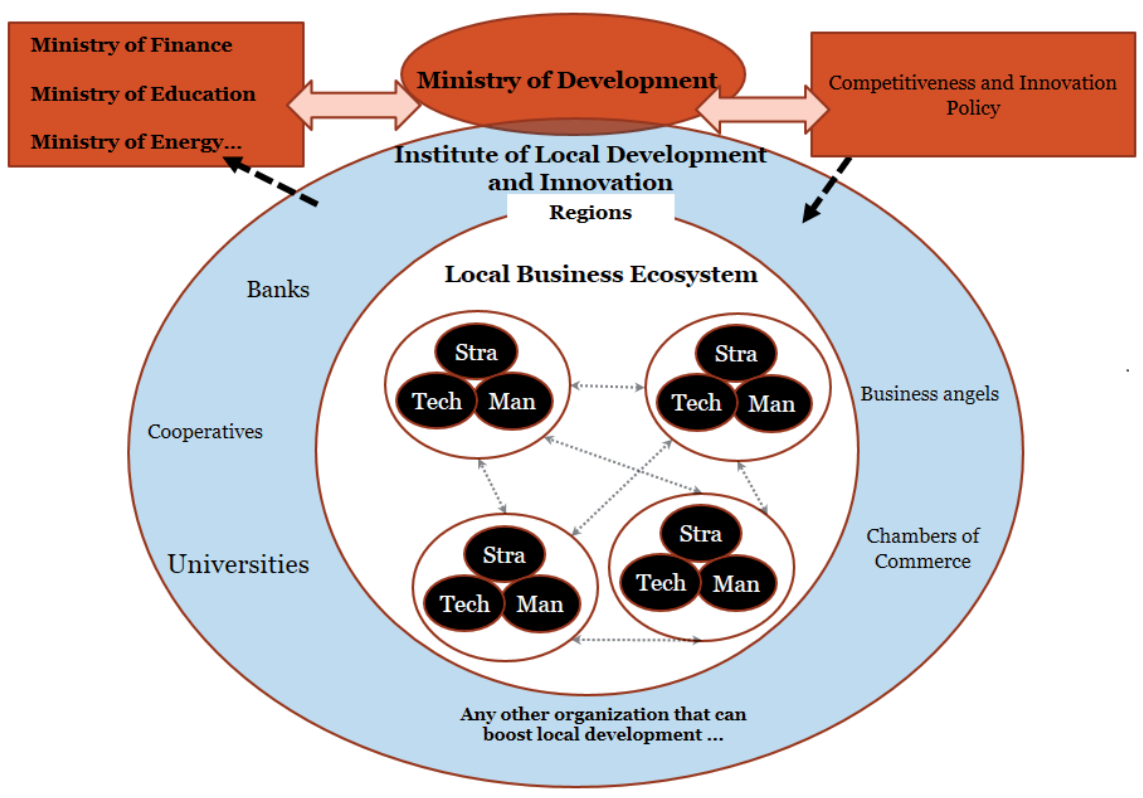

Figure 4. For a new business ecosystem policy in Greece

Bearing in mind that the fundamental objective of a modern ecosystem policy is to improve the environment, both external and internal, in which entrepreneurs and other stakeholders operate (Simatupang, Schwab, \& Lantu, 2015), the ILDIs aim to connect all those who communicate directly or indirectly with the local business ecosystem, providing a comprehensive framework of business consulting and advisory. The ILDI is a service center for entrepreneurship aimed at interconnecting public and private bodies and organizations. In this way, it strengthens the existing business ecosystem as it has access to actors that can support the locally established entrepreneurship.

The ILDI approach is a top-down and, at the same time, a bottom-up policy. The "living" capitalistic enterprise, which operates at the same time 
as a receptor of the policy intervention and as a generator of the central development procedure, is the cellular element of the local business ecosystem in Stra.Tech.Man terms (see Figure 5).

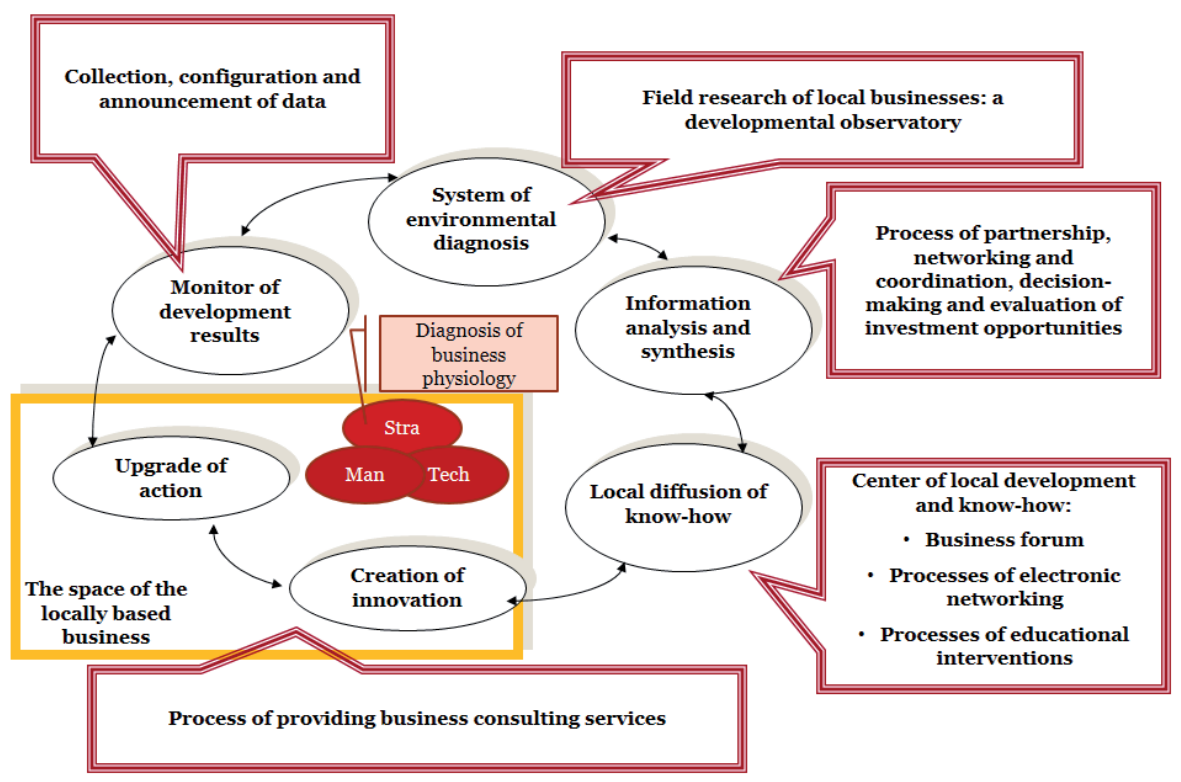

Figure 5. The mechanism of ILDI

The mechanism of ILDI:

- It can be a useful developmental link for the continuous competitive empowerment of the local enterprise and entrepreneurship.

- It can be an efficient center for the coordination, dissemination, and promotion of expertise at the local level, with the ultimate goal of reproducing the innovation and extroversion of the local entrepreneurial system.

- It can be an adaptive mechanism appropriate for enhancing, reproducing, and reorganizing the established dynamic value chain of local entrepreneurship.

The ILDI proposes a circular procedure that can diagnose the specific Stra. Tech.Man organizational physiology, provide consultation, and upgrade the innovative potential of local entrepreneurship while activating mechanisms of systematic feedback and monitoring of development results at the local level. 
The crisis and the SMEs in Greece: The business ecosystem of SMEs in the Eastern Macedonia and Thrace region

The Greek national socioeconomic system has continued to be under the shadow of a lasting structural crisis for more than a decade now. More profoundly than the macroeconomics of the phenomenon, a view that is limited to financial figures and results (Hardouvelis \& Gkionis, 2016; loannides \& Pissarides, 2015; Rapanos \& Kaplanoglou, 2014), what the Greek socioeconomic system is currently experiencing is a crisis in the overall socioeconomic development model (Aglietta, 2010; Boyer, 2015; Rosier, 1985; Schumpeter, 1939).

In particular, based on the results of the 2016-2017 annual entrepreneurship report from the Greek Foundation for Economic \&

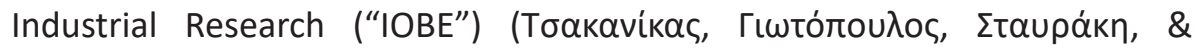

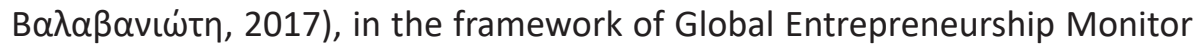
(GEM), the innovation and entrepreneurship environment is one of the worst in the European Union. The lack of a systematic policy support framework for entrepreneurship creates barriers to entrepreneurial activity in Greece. Significant obstacles to entrepreneurship also arise due to the difficulty of accessing funding, the high barriers to entry in the market, as well as the prevailing culture of entrepreneurship.

Thus, we see that the competitiveness problem of Greek SMEs is not merely "conjunctural" but structural. As the European 2017 SBA Fact Sheet for Greece (European Commission, 2018) notices, policy priorities for SMEs in Greece should include, among other things, the structuration of policies for the development of internationalized activities, entrepreneurship, linking universities to the real economy, while improvements in excessive regulatory burdens and administrative complexity are necessary. The report also notices that the main feature reflecting the competitiveness gap is the comparatively low value added: that is, productivity, measured as value added per the number of persons employed.

\section{Eastern Macedonia and Thrace regional economy}

The region of Eastern Macedonia and Thrace is one of the thirteen Greek regions and is a less developed border region that combines socioeconomic and cultural peculiarities and deficiencies. As a border region is both peripheral, because of its reduced socioeconomics relations with other areas, and disadvantageous due to the existence of inherent weaknesses that impede the development process (Blakely \& Leigh, 2013; Boudeville, 1974). 
To illustrate that, in Table 1, we calculate some key regional indicators that highlight the comparative lower growth of the region of Eastern Macedonia and Thrace.

Table 1. Eastern Macedonia and Thrace - regional figures

\section{Gross Value Added}

By industry, 2008 \& 2014* (EUR, current prices, in millions)

Selected Industries: AFF: Agriculture-Forestry-Fishing, MEG: Mining-Electricity-Gas, M: Manufacturing, C: Construction, TTAFS: Trade-Transportation-AccommodationFood Services, FIA: Financial and Insurance Activities, PSTA: Professional, Scientific and Technical Activities

\begin{tabular}{l|l|l|l|l|l|l|l|l}
\hline & AFF & MEG & M & C & TTAFS & FIA & PSTA & SUM \\
\hline $\begin{array}{l}\text { Eastern } \\
\begin{array}{l}\text { Macedonia } \\
\text { \& Thrace }\end{array}\end{array}$ & 499 & 298 & 947 & 439 & 2094 & 205 & 323 & 4805 \\
\hline $\begin{array}{l}\text { Eastern } \\
\begin{array}{l}\text { Macedonia } \\
\text { \& Thrace }\end{array}\end{array}$ & 433 & 248 & 689 & 180 & 1261 & 162 & 125 & 3098 \\
\hline
\end{tabular}

By region and sector, 2014* (EUR, current prices, in millions)

I= Primary, II= Secondary, III= Tertiary

\begin{tabular}{l|l|l|l|l}
\hline & I & II & III & TOTAL \\
\hline Greece & 5843 & 25047 & 126297 & 157187 \\
\hline $\begin{array}{l}\text { Eastern Macedonia } \\
\text { \& Thrace }\end{array}$ & 433 & 1117 & 4548 & 6098 \\
\hline
\end{tabular}

Location Quotient (LQ)

By region and sector, 2014 (based on Gross Value Added)

I= Primary, II= Secondary, III= Tertiary

\begin{tabular}{l|l|l|l}
\hline & LQ (I) & LQ (II) & LQ (III) \\
\hline $\begin{array}{l}\text { Eastern } \\
\text { Macedonia \& }\end{array}$ & 1.90746 & 1.14953 & 0.92821 \\
Thrace & & &
\end{tabular}

Thrace

Employment by region and sectors, 2014

\begin{tabular}{l|l|l|l|l}
\hline & I & II & III & TOTAL \\
\hline Greece & 488413 & 579473 & 2931410 & 3999296 \\
\hline Attica & 13705 & 210338 & 1303370 & 1527413 \\
\hline North Aegean & 8546 & 7809 & 52288 & 68643 \\
\hline South Aegean & 10460 & 19111 & 104041 & 133612 \\
\hline Crete & 41097 & 32908 & 163775 & 237780 \\
\hline
\end{tabular}

Entrepreneurship, Technological Upgrading and Innovation Policy in Less 


\begin{tabular}{l|l|l|l|l}
\hline $\begin{array}{l}\text { Eastern Macedonia } \\
\text { \& Thrace }\end{array}$ & 60086 & 26631 & 124086 & 210803 \\
\hline Central Macedonia & 87749 & 94586 & 453511 & 635846 \\
\hline Western Macedonia & 15693 & 21706 & 52446 & 89845 \\
\hline Epirus & 23081 & 17503 & 75983 & 116567 \\
\hline Thessaly & 62642 & 40684 & 159428 & 262754 \\
\hline lonian Islands & 12471 & 9608 & 59646 & 81725 \\
\hline Western Greece & 50926 & 27927 & 148379 & 227232 \\
\hline Central Greece & 39826 & 42907 & 111202 & 193935 \\
\hline Peloponnese & 62130 & 27754 & 123255 & 213139 \\
\hline
\end{tabular}

Regional Multiplier and Total Multiplier by region, 2014

\begin{tabular}{l|l|l|l|l}
\hline Attica & & & 7.09 & 8.31 \\
\hline North Aegean & 52.32 & & 26.5 & 32.13 \\
\hline South Aegean & & & 17 & 3.45 \\
\hline Crete & 3.4 & & & 19.71 \\
\hline $\begin{array}{l}\text { Eastern Macedonia \& } \\
\text { Thrace }\end{array}$ & 1.75 & & & 6.14 \\
\hline Central Macedonia & 79.8 & 38.6 & & 179 \\
\hline Western Macedonia & 3.32 & 2.5 & & 6.7 \\
\hline Epirus & 2.6 & 28.6 & & 12.32 \\
\hline Thessaly & 2.05 & 15.58 & & 46.36 \\
\hline Ionian Islands & 5 & & & 32.81 \\
\hline Western Greece & 2.2 & & & 9.8 \\
\hline Central Greece & 2.47 & 2.9 & & 6.26 \\
\hline Peloponnese & 1.72 & & & 5.9 \\
\hline
\end{tabular}

Source: based on Vlados, Deniozos, and Chatzinikolaou (2018).

Table 1 shows that the gross value added in selected productive sectors between 2008 and 2014, across the region, fell by 35.5\%, which is indicative of the economic crisis across the country. From the calculation of the location quotient (1) and according to the literature (Barff \& lii, 1988; Davis, 1990), when $L Q>1$ then the activity is standard or exporting, when $L Q<1$ then the activity is non-standard and when $L Q=1$ the activity is balanced.

Air $=$ Employment of sector $i$ and region $r$

$A r=$ Total employment of the region $r$

Ain $=$ Employment of sector $i$ in country's total

$A n=$ Total country's employment 
Location quotient:

$$
L Q=(A i r / A r) /(A i n / A n)
$$

Regional multiplier:

$$
\operatorname{Kir}=\operatorname{Air} /[\operatorname{Air}-(\operatorname{Ain} / A n) A r]
$$

Total regional multiplier:

$$
K r=A r / \text { Leir }
$$

Eeir $=$ Employment of total export activity of the region (There is no multiplying effect when eir $<0$ or eir $=0$ ):

$$
\text { eir }=\operatorname{Air}-(\operatorname{Ain} / \operatorname{Ain}) A r
$$

Therefore, the primary (I) and secondary (II) productive sectors of Eastern Macedonia and Thrace are basic, while the tertiary (III) sector is non-standard. These findings contrast with the gross value added of the tertiary sector, which is much higher than the primary and secondary sectors, something that suggests low cross-sectoral competitiveness of the enterprises operating in the region. Also, because the regional multiplier calculation (2) (3) results in a value greater than 1 (1.75), there is a multiplying effect and thus exporting activity only in the primary sector, even though the majority of the employees are in the tertiary sector. The regional multiplier measures the region's total raise of employment by taking into account the increase in the number of employed in export sectors (4) (Vlados, Deniozos, \& Chatzinikolaou, 2018). The regional multiplier shows that the region of Eastern Macedonia and Thrace is one of the least competitive regions of Greece, overall.

\section{FIELD RESEARCH}

In this work, we propose that the Stra.Tech.Man approach could be a mechanism to strengthen the competitiveness and innovation potential of small and medium-sized enterprises in a less developed region, such as Eastern Macedonia and Thrace. In this direction, we shared questionnaires, without weighing our sample, and obtained data from 45 SMEs operating in the region of Eastern Macedonia and Thrace, irrespective of their sector of activity. The majority of interviewed SMEs were active in the retail and 
food and beverages industry. One of the criteria we set was that enterprises had to employ a workforce of 20 or more people. Our final goal was the first investigation of how the Stra.Tech.Man physiology has changed for these enterprises and the region as a whole, in times of crisis.

This qualitative research (Shields \& Rangarajan, 2013) does not intend to discover, suggest and test a case of a general hypothesis (with full interpretative and predictive possibilities), nor to identify specific representative causality relationships. Specifically, we have emphasized the qualitative introduction of measuring the physiological evolution of specific enterprises, in terms of exploratory research (Stebbins, 2001). This exploratory research is an induction process (Neergaard \& Ulhøi, 2007) that attempts to generalize in qualitative terms, in such a way as to make it possible to investigate in the future the appropriate integrated cases. In the future, this research can be more comprehensive and empirically controllable by drawing data more systematically (Johnson, 2001).

\section{Presentation of the questionnaire}

The questionnaire (see Table 2) contains questions divided equally into the three dimensions of Stra.Tech.Man, to find out the particular physiology of the company. In the questionnaire, the average of scores marks three physiological types as follows:

- 0 and 1: Strong evidence that the enterprise is of monad-centered type;

- 2 and 3: Strong evidence that the enterprise is of massive type;

- 4 and 5: Strong evidence that the enterprise is of flexible type.

According to Vlados (2004, 2012; B $\lambda \alpha \dot{\delta}$ os, 2006), there are three major physiological categories for enterprises operating mainly in Greece, but also abroad: the monad-centered, the massive, and the flexible:

- The majority of enterprises operating in Greece are monad-centered. In the management dimension are following mostly their practical experience, their technological choices are usually sporadic and uncoordinated, and their central strategic logic is based solely on intuition and instinctive choices.

- The massive type of physiology focuses on the managerial specialization, a linear model of exploiting technology, and a strategy that depends on "mechanistic" efficiency and productivity. It does not deviate easily from the rule, based on the intensive exploitation of economies of scale. 
- The last type, the flexible enterprise, although not thriving in Greece, operates based on the extensive participation of members inside the enterprise. It seems able to assimilate the growing complexity in technological terms while facing its strategic challenges with a profound evolutionary logic. This firm is not only able to "play by the rules," but also with its innovative action can "change the rules" with its systematic innovation ability.

Table 2. A compressed form of the 45 answered questionnaires. Each question gets a score of 0 to 5 . The score of each question in the table shows the average of the 45 responses.

Stra.Tech.Man. physiology

\begin{tabular}{|c|c|c|c|c|c|c|c|c|c|c|c|}
\hline \multicolumn{10}{|c|}{ 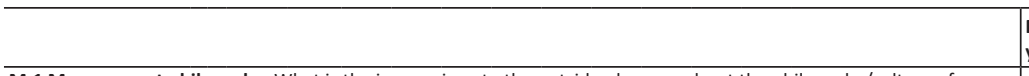 } & $\begin{array}{l}\text { Past five } \\
\text { years }\end{array}$ & Today \\
\hline \multicolumn{10}{|c|}{$\begin{array}{l}\text { M.1 Management philosophy: What is the image given to the outside observer about the philosophy/culture of } \\
\text { management that governs the enterprise? }\end{array}$} & \multirow[b]{2}{*}{2.53} & \multirow[b]{2}{*}{3.22} \\
\hline $\begin{array}{l}\text { Based on "traditional } \\
\text { values" }\end{array}$ & \multicolumn{2}{|c|}{$\begin{array}{l}\text { Based on market } \\
\text { experience }\end{array}$} & \multicolumn{2}{|c|}{$\begin{array}{l}\text { In the } \\
\text { transition to } \\
\text { the systematic } \\
\text { management }\end{array}$} & \multicolumn{2}{|c|}{\begin{tabular}{|l|} 
Systematic \\
management, \\
based on \\
measurements \\
and orders \\
\end{tabular}} & \multicolumn{2}{|c|}{\begin{tabular}{|l|} 
In the transition \\
from strict \\
hierarchical to \\
participatory \\
management \\
\end{tabular}} & \begin{tabular}{|l|} 
Systematic, \\
participatory \\
management, \\
based on teamwork \\
\end{tabular} & & \\
\hline \multicolumn{10}{|c|}{$\begin{array}{l}\text { M.2 Family character and tradition: To what extent has the departure of the founder's (and/or his/her family) "face" } \\
\text { affected the administration of the enterprise? }\end{array}$} & 1.09 & 1.04 \\
\hline \multicolumn{10}{|c|}{ M.3 Organizing and organization chart: The organizational chart of the company gives an image of a business that has: } & \multirow[b]{2}{*}{2.91} & \multirow[b]{2}{*}{3.49} \\
\hline $\begin{array}{l}\text { Informal, ambiguous and } \\
\text { fluid structure }\end{array}$ & \multicolumn{2}{|c|}{$\begin{array}{l}\text { Been paving the } \\
\text { way for a clear } \\
\text { organizational } \\
\text { structure }\end{array}$} & \multicolumn{2}{|c|}{$\begin{array}{l}\text { Clear } \\
\text { organizational } \\
\text { structure } \\
\text { but not fully } \\
\text { covering its } \\
\text { organizational } \\
\text { needs }\end{array}$} & \multicolumn{2}{|c|}{\begin{tabular}{|l|} 
Full \\
systematization, \\
with \\
"centralized" \\
organizational \\
structure
\end{tabular}} & \multicolumn{2}{|c|}{\begin{tabular}{|l|} 
A modest \\
organizational \\
structure \\
that meets \\
organizational \\
needs with \\
limited use of \\
decentralization \\
\end{tabular}} & $\begin{array}{l}\text { A flexible } \\
\text { organizational } \\
\text { structure of } \\
\text { multidimensional } \\
\text { decentralization }\end{array}$ & & \\
\hline \multicolumn{10}{|c|}{$\begin{array}{l}\text { M.4 Administration and labor relations: To what extent is there a well-developed and fertile framework of labor } \\
\text { relations management centered on modern forms of motivation and leadership within the enterprise (business } \\
\text { climate)? }\end{array}$} & 3.00 & 3.71 \\
\hline \multicolumn{10}{|c|}{$\begin{array}{l}\text { M.5 Intra-company training and development of human resources: To what extent does the enterprise have and } \\
\text { utilize a systematic framework for intra-company training and human resources development? }\end{array}$} & 3.27 & 3.93 \\
\hline \multicolumn{10}{|c|}{$\begin{array}{l}\text { M.6 Social responsibility and action: To what extent does the enterprise manage to cultivate and develop the image of } \\
\text { social responsibility and sensitivity? }\end{array}$} & 2.87 & 3.56 \\
\hline \multicolumn{10}{|c|}{$\begin{array}{l}\text { M.7 External contact mechanism: To what extent is an external communication and public relations department, } \\
\text { capable of informing the outside observer of the enterprise, present? }\end{array}$} & 2.60 & 3.64 \\
\hline \multicolumn{10}{|c|}{$\begin{array}{l}\text { M.8 Certified quality management: To what extent is a systematic quality management framework, followed by ISO } \\
\text { quality certification, in place? }\end{array}$} & \multirow[b]{2}{*}{3.11} & \multirow[b]{2}{*}{3.62} \\
\hline \multirow[t]{2}{*}{ Not at all } & $\begin{array}{l}\text { A phase of } \\
\text { a preliminary } \\
\text { study }\end{array}$ & \multicolumn{2}{|c|}{$\begin{array}{l}\text { A phase of } \\
\text { quality control } \\
\text { implementation }\end{array}$} & \multicolumn{2}{|c|}{$\begin{array}{l}\text { Quality control } \\
\text { operation } \\
\text { focused on the } \\
\text { production } \\
\text { process }\end{array}$} & \multicolumn{2}{|c|}{$\begin{array}{l}\text { Quality } \\
\text { assurance } \\
\text { through quality } \\
\text { certification } \\
\text { (of ISO type) } \\
\text { of the whole } \\
\text { enterprise } \\
\end{array}$} & \multicolumn{2}{|c|}{$\begin{array}{l}\text { Complete methodology } \\
\text { of Total Quality } \\
\text { Management centered on } \\
\text { the enterprise's people } \\
\text { and groups }\end{array}$} & & \\
\hline & & & & & & & & anagem & ment total - Average & 2.67 & 3.28 \\
\hline \multicolumn{10}{|c|}{$\begin{array}{l}\text { T.1 Phase of potential technological development: By looking at the overall technological potential of the enterprise, } \\
\text { you would primarily characterize it as }\end{array}$} & \multirow{3}{*}{3.51} & \multirow[b]{2}{*}{4.00} \\
\hline \begin{tabular}{l|l} 
Almost outdated & 0 \\
a \\
tr
\end{tabular} & $\begin{array}{l}\text { downward } \\
\text { rend }\end{array}$ & $\begin{array}{l}\text { With } \\
\text { a do } \\
\text { trenc }\end{array}$ & $\begin{array}{l}\text { signs of } \\
\text { wnward } \\
\text { d }\end{array}$ & $\begin{array}{l}\text { In a } \\
\text { cond }\end{array}$ & $\begin{array}{l}\text { stable } \\
\text { lition }\end{array}$ & In pro & ogress & $\begin{array}{l}\text { In the } \\
\text { robust }\end{array}$ & $\begin{array}{l}\text { emergence of } \\
\text { st new data }\end{array}$ & & \\
\hline \multicolumn{10}{|c|}{$\begin{array}{l}\text { T.2 Modernization of facilities: To what extent has a general program of modernization and extension of the } \\
\text { enterprise's manufacturing facilities been implemented? }\end{array}$} & & 3.64 \\
\hline
\end{tabular}




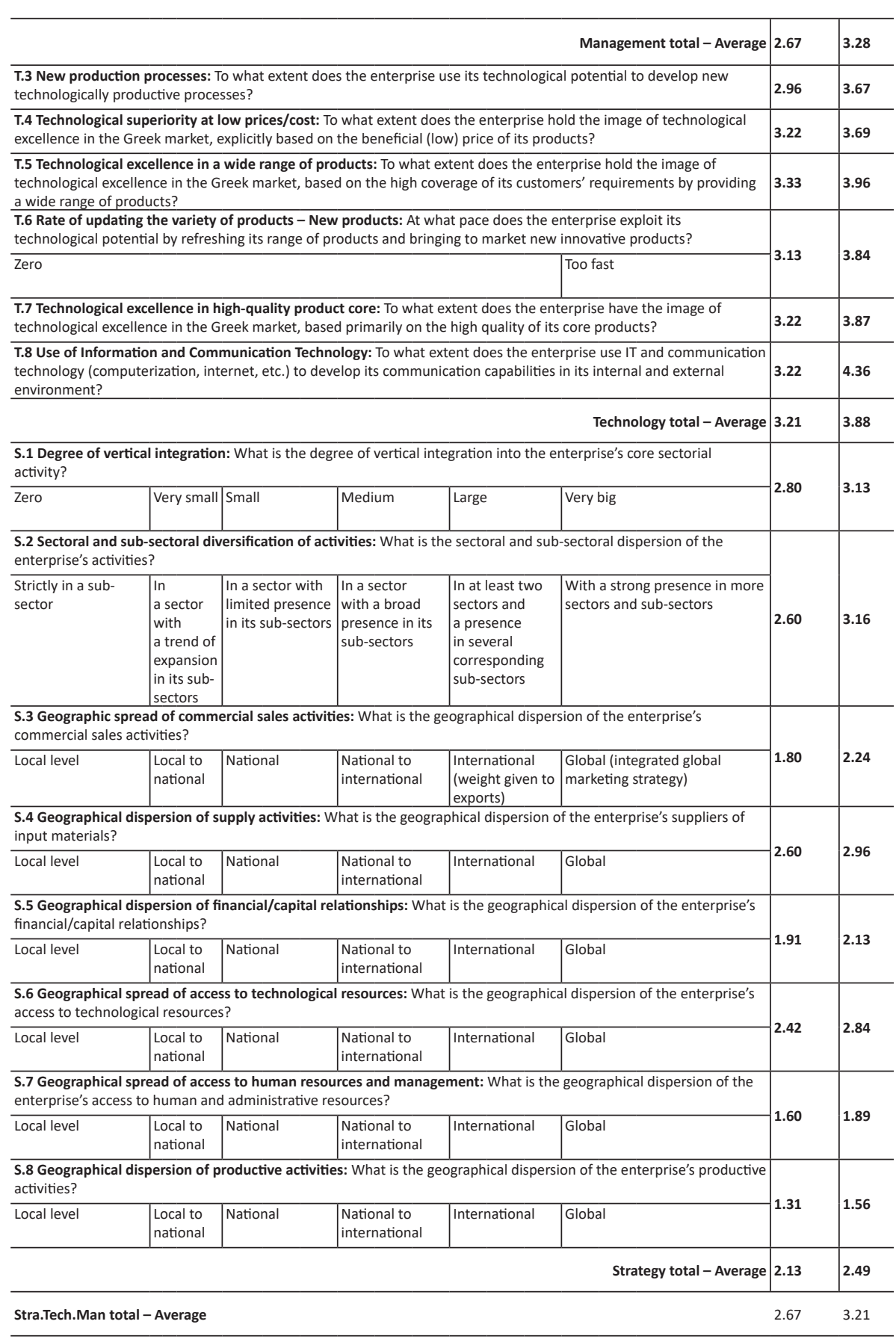




\section{Presentation and analysis of findings}

Therefore, we can now make a first generalization of how the physiology of sample changes over the past five years, according to the views of the questioned sample. Based on the 24 questions, we can summarize the following notes:

\section{Management dimension:}

M1. Management philosophy has a relatively weak tendency towards systematization. It is worth mentioning that hardly any answer comments on or justifies the process of this systematization explicitly.

M2. The family character of the enterprise is not only present but also is reinforced in the crisis conditions.

M3. In theory, the trend towards massiveness shows that a small and medium-sized enterprise can evolve, under specific conditions, into massive. In practice, however, such a move requires investment in managerial capacities and expertise. In this context, we did not find any comments in the questionnaire to present these investments.

M4. In the same logic, leadership and administration seem to evolve slowly towards a more systematic logic, although there is insufficient clarification from the respondents to justify this high score fully.

M5. Many monad-centered enterprises, operating based on "business instinct," believe that they ensure conditions that are "more humane" for their workforce. This seems to be the case here, as there is also no definite answer justifying this evolution of physiology via systematic forms of incompany training.

M6. In terms of social responsibility and action, the respondents have not justified this trend towards massiveness and more systematization explicitly. M7. The extroversion of these enterprises seems to increase slowly.

M8. The quality management of the sample seems to grow, but the replies of the respondents do not justify this trend entirely.

Overall, in terms of management, the answers converge to the observation that during the crisis, there is an effort of managerial systemization, although with overall weak results in terms of physiological transition.

\section{Technology dimension:}

T1. The technological potential seems to develop progressively, although without explicit mention by the respondents on how they draw, disseminate, and utilize this potential. 
T2. A specific modernization of facilities seems to be in progress, although the respondents do not specify the level and extent of relative investments. T3. The use of new technology seems to increase relatively productivity; however, the entrepreneurs do not specify their methods of continuous technological amelioration explicitly.

T4. The importance of technological amelioration based on the low price of products seems to increase.

T5. Our sample perceives the same trend about providing a more extensive range of products.

T6. The pace of change in the augmentation of variety of products seems to rise slowly.

T7. The core product in terms of technology seems to claim progressively higher quality, although the answers do not indicate the relative chosen procedures.

T8. The use of information technology seems to be in a relatively developing and integrating trajectory.

Overall, in terms of technology, the answers converge to the finding that during the crisis, there is a relative effort of technological modernization, although with overall weak results in terms of total physiological transition.

\section{Strategy dimension:}

S1. The vertical integration is relatively weak as strategic output.

S2. Sectoral dispersion has a tendency of limited presence in direct subsectors.

S3. Geographical dispersion of sales tends to overcome the narrow local level during the crisis, towards a national presence.

S4. Geographical dispersion of suppliers appears relatively small, tending to move in a more expanded spatial range.

S5. The same trend, although declining, applies to the financial dispersion. These enterprises seem that they cannot escape their local "frontiers" to find financial resources.

S6. Although we have received relatively "optimistic" responses about the more and more expanded use of information technology, the access to strategic resources seems to remain limited to the local-national level. This suggests a relatively narrow concept and use of new strategic directions.

S7. The employment of human resources seems to be limited to the local and national level.

S8. There is an increase in the dispersion of the enterprise's productive activities, which however remains limited at the local level. 
Overall, in terms of strategy, the answers converge to the finding that during the crisis, there is an attempt of strategic repositioning, although with overall weak results in terms of physiological and structural transition.

\section{CONCLUSIONS, LIMITATIONS AND FUTURE RESEARCH}

Nowadays, the literature on local development (analyzed in clusters and business ecosystems terms) shows that there is an increasing tendency of "biological" study to the dynamic evolution of enterprises (Alvedalen \& Boschma, 2017; Baldwin, 2012; Bosch \& Olsson, 2018; Cavallo, Ghezzi, \& Balocco, 2018; Iansiti \& Levien, 2004; Isenberg, 2010; Liu \& Rong, 2015; Moore, 1993; Williamson \& Meyer, 2012; Zahra \& Nambisan, 2012). In this context, we can understand clearly that the enterprises are socioeconomic organizations that lie at the evolving epicenter of all business ecosystems in globalization. However, there seems to be no explicit, applied methodology, in terms of policy articulation, to enhance the competitiveness of the local business ecosystems (Rinkinen \& Harmaakorpi, 2018).

In this context, by applying the concept of Stra.Tech.Man transformative physiology of the enterprise, we have tried to propose a new approach of business ecosystems comprehension and policy articulation. The data from our research show that the vast majority of the sample enterprises we studied have a relatively low systematization in articulating their strategic, technological and managerial potential; the location of these enterprises, that is, a less favored business ecosystem and one of the less developed European regions is related to this observation. Specifically, we have found in this study indications that a relatively stable evolution of "physiological" type exists in the sample of these enterprises. The three spheres of strategy, technology and management seem, in the vast majority of cases, to co-evolve into an increasing business processes systematization direction (Chang, 2016; Rosemann \& vom Brocke, 2015), within the current crisis conditions of the Greek economy. We have not observed any extreme deviation from the Stra.Tech.Man dimensions' co-evolution and, therefore, the evolution of each sphere is not independent and distant from the "physiological data" of these enterprises. In this context, it is valid to argue that a consistent physiological "hybridism" (Battilana \& Dorado, 2010; McMullen, 2018), without physiological leaps (Marshall, 1890) or/and extremely varied Stra. Tech.Man syntheses are present.

In light of the above findings, we think that the Stra.Tech.Man approach, under specific conditions, can be the basis for a qualitative method of studying the evolutionary physiology of enterprises; and, by extension, an instrument 
for understanding and monitoring the specific strategic, technological and managerial needs of the enterprises on a local scale, in order to assist the articulation of appropriate policies to enhance them. Overall, therefore, we think that the Stra.Tech.Man physiology approach can be a useful analytical tool for both the enterprises to understand their evolutionary dynamics and prospects and to develop their innovative capacity, as well as for the articulation of local development policies.

However, the implementation of this approach in the field is in the initial phase of development and, as expected, it has several limitations:

1) It does not yet have a final operational form, which could combine qualitative and quantitative dimensions to implement more comprehensive field research.

2) It has not tested a sufficient number of firm cases and different local business ecosystems.

3) It has not reached a final investigative content so that an "action research" can ameliorate and enrich the results (Coghlan \& Brannick, 2014; Eden \& Ackermann, 2018).

These limitations, indeed, seem to be the reason why the average score of the Stra.Tech.Man physiology of the sample enterprises we studied does not reflect the competitiveness potential of the Eastern Macedonia and Thrace region's business ecosystem. The respondents probably "beautified" their responses to some extent, which cannot be identified clearly with the method we applied in this research.

Our research team should try to remove in the future these limitations and develop a complete applied investigational tool and, furthermore, a new policy framework. In future field research, in which the respondent would answer the Stra.Tech.Man physiology questions with the guidance of a business research consultant and with a composite qualitative-quantitative tool of investigation, we think the responses would be significantly more precise.

Furthermore, a representative sample of enterprises can also be particularly useful in articulating relevant policy support. In this direction, a mechanism such as the Institute of Local Development and Innovation, which can combine elements from other effective local policies, like the ones we presented in this article, can function as a "business clinic" that can serve the locally based "business-patient," for all sectors and types of enterprises in the local business ecosystem. Of course, an overall evaluation of the existing policies performing similar roles in the regions in future research is necessary. 


\section{References}

Acs, Z. J., Stam, E., Audretsch, D. B., \& O'Connor, A. (2017). The lineages of the entrepreneurial ecosystem approach. Small Business Economics, 49(1), 1-10. https://doi.org/10.1007/s11187-017-9864-8

Acs, Z. J., Audretsch, D. B., Lehmann, E. E., \& Licht, G. (2017). National systems of innovation. The Journal of Technology Transfer, 42(5), 997-1008. https://doi.org/10.1007/s10961-016-9481-8

Adner, R., \& Kapoor, R. (2010). Value creation in innovation ecosystems: How the structure of technological interdependence affects firm performance in new technology generations. Strategic Management Journal, 31(3), 306-333. https://doi.org/10.1002/smj.821

Aglietta, M. (2010). La Crise: Le Voies de Sortie (Nouv. éd). Paris: Michalon.

Ahokangas, P., Boter, H., \& livari, M. (2018). Ecosystems perspective on entrepreneurship. In R. V. Turcan \& N. M. Fraser (Eds.), The Palgrave Handbook of Multidisciplinary Perspectives on Entrepreneurship (pp. 387-407). Cham: Springer International Publishing. https://doi. org/10.1007/978-3-319-91611-8_18

Akola, E., \& Havupalo, N. (2013). Restructuring in SMEs: Finland. Luxembourg: Publications Office of the European Union.

Alvedalen, J., \& Boschma, R. (2017). A critical review of entrepreneurial ecosystems research: Towards a future research agenda. European Planning Studies, 25(6), 887-903. https://doi.org/10.1080/09654313.2 017.1299694

Asheim, B. T., Grillitsch, M., \& Trippl, M. (2016). Regional innovation systems: Past-present-future. In R. Shearmur, C. Carrincazeaux, \& D. Doloreux, Handbook on the Geographies of Innovation (pp. 45-62). Cheltenham, UK; Northampton, MA: Edward Elgar Publishing. https:// doi.org/10.4337/9781784710774.00010

Autio, E., \& Levie, J. (2017). Management of entrepreneurial ecosystems. In G. Ahmetoglu, T. Chamorro-Premuzic, B. Klinger, \& T. Karcisky (Eds.), The Wiley Handbook of Entrepreneurship (pp. 423-449). Hoboken, New Jersey: Wiley-Blackwell. https://doi.org/10.1002/9781118970812.ch19

Baldwin, C. Y. (2012). Organization design for business ecosystems. Journal of Organization Design, 1(1), 20-23. https://doi.org/10.7146/jod.6334

Barca, F., McCann, P., \& Rodríguez-Pose, A. (2012). The case for regional development intervention: Place-based versus place-neutral approaches. Journal of Regional Science, 52(1), 134-152. https://doi.org/10.1111/ j.1467-9787.2011.00756.x

Barff, R. A., \& lii, P. L. K. (1988). Dynamic shift-share analysis. Growth and Change, 19(2), 1-10. https://doi.org/10.1111/j.1468-2257.1988.tb00465.x

Bathelt, H., Malmberg, A., \& Maskell, P. (2004). Clusters and knowledge: Local buzz, global pipelines and the process of knowledge creation. Progress in Human Geography, 28(1), 31-56. https://doi. org/10.1191/0309132504ph469oa 
Batterton, K. A., \& Hale, K. N. (2017). The Likert scale what it is and how to use it. Phalanx, 50(2), 32-39.

Battilana, J., \& Dorado, S. (2010). Building sustainable hybrid organizations: The case of commercial microfinance organizations. Academy of Management Journal, 53(6), 1419-1440. https://doi.org/10.5465/ amj.2010.57318391

Becattini, G. (1979). Dal settore industriale al distretto industriale. Alcune considerazioni sull'unità d'indagine dell'economia industriale. Rivista Di Economia e Politica Industriale, V(1), 7-21.

Belussi, F., \& Caldari, K. (2008). At the origin of the industrial district: Alfred Marshall and the Cambridge school. Cambridge Journal of Economics, 33(2), 335-355. https://doi.org/10.1093/cje/ben041

Ben Letaifa, S., Gratacap, A., Isckia, T., \& Pesqueux, Y. (2013). Understanding Business Ecosystems: How Firms Succeed in the New World of Convergence? Bruxelles: De Boeck.

Blackburn, R. A. (2016). Government, SMEs and Entrepreneurship Development: Policy, Practice and Challenges. London; New York: Routledge. https://doi.org/10.4324/9781315585666

Blakely, E. J., \& Leigh, N. G. (2013). Planning Local Economic Development: Theory and Practice (Fifth edition). Los Angeles: SAGE.

Blondel, F., \& Gratacap, A. (2016). Entrepreneur, dynamique d'innovation et écosystème d'affaires. Marché et organisations, 1(25), 15-28. https:// doi.org/10.3917/maorg.025.0015

Bosch, J., \& Olsson, H. H. (2018). Ecosystem traps and where to find them. Journal of Software: Evolution and Process, 30(11), 1-16. https://doi. org/10.1002/smr.1961

Boudeville, J. R. (1974). Problems of Regional Economic Planning. Edinburgh: Edinburgh University Press.

Boyer, R. (2015). Économie Politique des Capitalismes: Théorie de la Régulation et des Crises. Paris: La Découverte. https://doi.org/10.4000/ regulation.11923

Camagni, R. (1995). Espace et temps dans le concept de milieu innovateur. In A. Rallet \& A. Torre (eds.), Economie Industrielle et Economie Spatiale (pp. 192-210). Paris: Economica.

Carroué, L. (2002). Géographie De La Mondialisation. Paris: Armand Colin.

Cavallo, A., Ghezzi, A., \& Balocco, R. (2018). Entrepreneurial ecosystem research: Present debates and future directions. International Entrepreneurship and Management Journal, 1-31. https://doi. org/10.1007/s11365-018-0526-3

Chang, J. F. (2016). Business Process Management Systems: Strategy and Implementation. New York: Auerbach Publications. https://doi. org/10.1201/9781420031362

Coghlan, D., \& Brannick, T. (2014). Doing Action Research in Your Own Organization (4th ed.). Los Angeles; London; New Delhi; Singapore; Washington DC: SAGE. 
Cooke, P., Clifton, N., \& Oleaga, M. (2005). Social capital, firm embeddedness and regional development. Regional Studies, 39(8), 1065-1077. https:// doi.org/10.1080/00343400500328065

Davis, H. C. (1990). Regional Economic Impact Analysis and Project Evaluation. Vancouver: University of British Columbia Press.

Delapierre, M., Moati, P., \& Mouhoud, E. M. (2000). Connaissance Et Mondialisation. Paris: Economica.

Eden, C., \& Ackermann, F. (2018). Theory into practice, practice to theory: Action research in method development. European Journal of Operational Research, 271(3), 1145-1155. https://doi.org/10.1016/j. ejor.2018.05.061

Elinkeinoelämän keskusliitto. (2018, January 3). EK:n yrityskysely: Lähes 60 \% vientiyrityksistä tarvitsee ja 26 \% käyttää Team Finlandin palveluita. Retrieved October 10, 2018, from https://ek.fi/ajankohtaista/ tiedotteet/2018/01/03/ekn-yrityskysely-lahes-60-vientiyrityksistatarvitsee-ja-26-kayttaa-team-finlandin-palveluita/

Etzkowitz, H. \& Zhou, C. (2017). The Triple Helix: University-IndustryGovernment Innovation and Entrepreneurship. London: Routledge. https://doi.org/10.4324/9781315620183

Eurofound. (2013). Restructuring in SMEs in Europe. Luxembourg: Publications Office of the European Union.

European Commission (2018) SBA Fact Sheet Greece. Retrieved March 7, 2019, from https://ec.europa.eu/docsroom/documents/32581/ attachments/13/translations/en/renditions/native

European Monitoring Centre on Change. (2018a, July 22). Poles of competitiveness | Eurofound [Restructuring Support Instruments]. Retrieved October 10, 2018, from https://www.eurofound.europa.eu/ observatories/emcc/erm/support-instrument/poles-of-competitiveness

European Monitoring Centre on Change. (2018b, August 7). Public Investment Bank | Eurofound [Restructuring Support Instruments]. Retrieved October 10, 2018, from https://www.eurofound.europa.eu/ observatories/emcc/erm/support-instrument/public-investment-bank

European Monitoring Centre on Change. (2018c, August 7). Team Finland-Services supporting the internationalisation of busi... | Eurofound [Restructuring Support Instruments]. Retrieved October 10, 2018, from https://www. eurofound.europa.eu/observatories/emcc/erm/support-instrument/teamfinland-services-supporting-the-internationalisation-of-busi

European Monitoring Centre on Change. (2018d, September 18). Innovation Norway | Eurofound [Restructuring Support Instruments]. Retrieved October 10, 2018, from https://www.eurofound.europa.eu/ observatories/emcc/erm/support-instrument/innovation-norway

European Monitoring Centre on Change. (2018e, September 26). Enterprise Ireland | Eurofound [Restructuring Support Instruments]. Retrieved October 11, 2018, from https://www.eurofound.europa.eu/ observatories/emcc/erm/support-instrument/enterprise-ireland 
European Monitoring Centre on Change. (2018f, September 26). Local Enterprise Offices (LEOs) | Eurofound [Restructuring Support Instruments]. Retrieved October 11, 2018, from https://www. eurofound.europa.eu/observatories/emcc/erm/support-instrument/ local-enterprise-offices-leos

European Monitoring Centre on Change. (2018g, October 2). Enterprise Ireland Mentor Network | Eurofound [Restructuring Support Instruments]. Retrieved October 11, 2018, from https://www.eurofound.europa. eu/observatories/emcc/erm/support-instrument/enterprise-irelandmentor-network

Foray, D., David, P. A., \& Hall, B. (2009). Smart specialisation-the concept. Knowledge Economists Policy Brief, 9(85), 1-5.

Forrester, J. W. (1984). Principes des Systèmes. Lyon: Presses Universitaires de Lyon.

Frederickson, H. G. (2016). The Adapted City: Institutional Dynamics and Structural Change: Institutional Dynamics and Structural Change. London; New York: Routledge. https://doi.org/10.4324/9781315290171

Harpe, S. E. (2015). How to analyze Likert and other rating scale data. Currents in Pharmacy Teaching and Learning, 7(6), 836-850. https://doi. org/10.1016/j.cptl.2015.08.001

Gancarczyk, M., \& Bohatkiewicz, J. (2018). Research streams in cluster upgrading: A literature review. Journal of Entrepreneurship, Management and Innovation, 14(4), 17-42. https://doi.org/10.7341/20181441

Georgescu-Roegen, N. (1971). The Entropy Law and the Economic Process. Cambridge, Mass: Harvard University Press. https://doi.org/10.4159/ harvard.9780674281653

Geus, A. de. (2002). The Living Company. Boston, Mass: Harvard Business School Press.

Golejewska, A. (2018). Innovativeness of enterprises in Poland in the regional context. Journal of Entrepreneurship, Management and Innovation, 14(1), 29-44. https://doi.org/10.7341/20181412

Gowdy, J. (1997). Introduction: Biology and economics. Structural Change and Economic Dynamics, 8(4), 377-383. https://doi.org/10.1016/S0954349X(97)00021-0

Haddad, E. A. (2018). Regional Inequality and Structural Changes: Lessons from the Brazilian Experience. London: Routledge. https://doi. org/10.1201/9780429449406

Hammerstein, P., \& Hagen, E. H. (2005). The second wave of evolutionary economics in biology. Trends in Ecology \& Evolution, 20(11), 604-609. https://doi.org/10.1016/j.tree.2005.07.012

Hanusch, H., \& Pyka, A. (2007). Elgar Companion to Neo-Schumpeterian Economics. Cheltenham, UK: Edward Elgar Publishing. https://doi. org $/ 10.4337 / 9781847207012$

Hardouvelis, G. A., \& Gkionis, I. (2016). A decade long economic crisis: Cyprus versus Greece. Cyprus Economic Policy Review, 10(2), 3-40. 
Harlé, E., \& Jouanneault, J.-D. (1983). L'Entreprise en Tant que Système. Lyon: Presses Universitaires de Lyon.

Hirsch, J., \& Roth, R. (1986). Das neue Gesicht des Kapitalismus: Vom Fordismus zum Post-Fordismus. Hamburg: VSA-Verlag.

Holloway, J. (1988). The great bear, post-fordism and class struggle: A comment on Bonefeld and Jessop. Capital \& Class, 12(3), 93-104. https://doi.org/10.1177/030981688803600105

Hurley, J., \& Storrie, D. W. (2017). Globalisation Slowdown? Recent Evidence of Offshoring and Reshoring in Europe. Luxembourg: Publications Office of the European Union.

lansiti, M., \& Levien, R. (2002). The new operational dynamics of business ecosystems: Implications for policy, operations and technology strategy. Harvard Business School Working Paper, (03-030).

Iansiti, M., \& Levien, R. (2004). The Keystone Advantage: What the New Dynamics of Business Ecosystems mean for Strategy, Innovation, and Sustainability. Boston, Mass: Harvard Business School Press.

Innovasjon Norge (2017). Annual Report 2017. Retrieved March 7, 2019, from https://arsrapport.innovasjonnorge.no/en/arsrapport-2017-eng/

Ioannides, Y. M., \& Pissarides, C. A. (2015). Is the Greek crisis one of supply or demand? Brookings Papers on Economic Activity, 2015(2), 349-373. https://doi.org/10.1353/eca.2015.0004

Isaksen, A., Tödtling, F., \& Trippl, M. (2018). Innovation policies for regional structural change: Combining actor-based and system-based strategies. In A. Isaksen, R. Martin, \& M. Trippl (Eds.), New Avenues for Regional Innovation Systems - Theoretical Advances, Empirical Cases and Policy Lessons (pp. 221-238). Cham: Springer International Publishing. https:// doi.org/10.1007/978-3-319-71661-9_11

Isckia, T., \& Lescop, D. (2009). Open innovation within business ecosystems: A tale from amazon.com, Communications \& Strategies, (74), 37-54.

Isenberg, D. (2010). The big idea: How to start an entrepreneurial revolution. Harvard Business Review, 88(6), 40-50.

Jacobides, M. G., Cennamo, C., \& Gawer, A. (2018). Towards a theory of ecosystems. Strategic Management Journal, 39(8), 2255-2276. https:// doi.org/10.1002/smj.2904

Jensen, M. B., Johnson, B., Lorenz, E., \& Lundvall, B.-Å. (2016). Forms of knowledge and modes of innovation. In B-Å. Lundvall, The Learning Economy and the Economics of Hope (Vol. 155, pp. 155-182). London: Anthem Press.

Jessop, B. (1988). Regulation theory, post fordism and the state: More than a reply to Werner Bonefield. Capital \& Class, 12(1), 147-168. https://doi. org/10.1177/030981688803400110

Johnson, B. (2001). Toward a new classification of nonexperimental quantitative research. Educational Researcher, 30(2), 3-13. https://doi. org/10.3102/0013189X030002003 
Katimertzopoulos, F., \& Vlados, C. (2017). Local support mechanisms for entrepreneurship: The approach of local development and innovation institutions. International Journal of Business and Economic Sciences Applied Research, 10(1), 30-41. https://doi.org/10.25103/ijbesar.101.04

Kennedy, E. B., Miller, D. J., \& Niewiarowski, P. H. (2018). Industrial and biological analogies used creatively by business professionals. Creativity Research Journal, 30(1), 54-66. https://doi.org/10.1080/10400419.201 7.1411631

Ketels, C. (2011). Clusters and competitiveness: Porter's contribution. In R. Huggins \& H. Izushi, Competition, Competitive Advantage, and Clusters: The Ideas of Michael Porter (pp. 173-192). Oxford: Oxford University Press. https://doi.org/10.1093/acprof:0so/9780199578030.003.0010

Kim, S.-T. (2015). Regional advantage of cluster development: A case study of the San Diego biotechnology cluster. European Planning Studies, 23(2), 238-261. https://doi.org/10.1080/09654313.2013.861807

Korhonen, J. (2001). Four ecosystem principles for an industrial ecosystem. Journal of Cleaner Production, 9(3), 253-259. https://doi.org/10.1016/ S0959-6526(00)00058-5

Kurtz, C. (2018). Are we ready for complexity? Journal on Policy and Complex Systems, 4(1), 135-154. https://doi.org/10.18278/jpcs.4.1.7

Laudicina, P. A., \& Peterson, E. R. (2016). From Globalization to Islandization (Global Business Policy Council (GBPC) /Research Report) (p. 26). ATKearney. Retrieved March 3, 2019, from https://www.atkearney.com/web/globalbusiness-policy-council/article?/a/from-globalization-to-islandization

Lazzeretti, L., Sedita, S. R., \& Caloffi, A. (2014). Founders and disseminators of cluster research. Journal of Economic Geography, 14(1), 21-43. https:// doi.org/10.1093/jeg/lbs053

Lesourne, J. (1976). Les Systèmes du Destin. Paris: Dalloz.

Li, Y. R. (2014). The cluster policies to nation competitiveness based on business ecosystem perspective - Case study of Taiwanese smart phone industry. In 2014 IEEE International Conference on Industrial Engineering and Engineering Management (pp. 887-891). https://doi.org/10.1109/ IEEM.2014.7058766

Liguori, E., Winkler, C., Hechavarria, D., \& Lange, J. (2018). Guest editorial. Journal of Enterprising Communities: People and Places in the Global Economy, 12(2), 86-91. https://doi.org/10.1108/JEC-02-2018-0017

Liu, G., \& Rong, K. (2015). The nature of the co-evolutionary process: Complex product development in the mobile computing industry's business ecosystem. Group \& Organization Management, 40(6), 809-842. https:// doi.org/10.1177/1059601115593830

Local Enterprise Offices. (2018). About US | Services. Retrieved October 11, 2018, from https://www.localenterprise.ie/About-Us/Services/

Mack, E., \& Mayer, H. (2016). The evolutionary dynamics of entrepreneurial ecosystems. Urban Studies, 53(10), 2118-2133. https://doi. org $/ 10.1177 / 0042098015586547$ 
Majava, J., Rinkinen, S., \& Harmaakorpi, V. (2016). Development of San Diego life sciences ecosystem. In Finnish policy research seminar: Growth ecosystems as an innovation policy tool. The Ministry of Economic Affairs and Employment of Finland.

Malecki, E. J. (2018). Entrepreneurship and entrepreneurial ecosystems. Geography Compass, 12(3), e12359. https://doi.org/10.1111/gec3.12359

Maroufkhani, P., Wagner, R., \& Wan Ismail, W. K. (2018). Entrepreneurial ecosystems: a systematic review. Journal of Enterprising Communities: People and Places in the Global Economy, 12(2), 158-177. https://doi. org/10.1108/JEC-03-2017-0025

Marshall, A. (1890). Principles of Economics (8th Edition, published in 1920). London: Macmillan.

Mason, C., \& Brown, D. R. (2014). Entrepreneurial Ecosystems and Growth Oriented Entrepreneurship (p. 38). The Hauge, Netherlands: OECD.

McMullen, J. S. (2018). Organizational hybrids as biological hybrids: Insights for research on the relationship between social enterprise and the entrepreneurial ecosystem. Journal of Business Venturing, 33(5), 575590. https://doi.org/10.1016/j.jbusvent.2018.06.001

Meier zu Köcker, G., \& Müller, L. (2015). Cluster Programmes in Europe (European Cluster Observatory) (p. 35).

Meyer, C., \& Davis, S. M. (2003). It's Alive: The Coming Convergence of Information, Biology, and Business. New York: Crown Business.

Moore, J. (1993). Predators and prey: A new ecology of competition. Harvard Business Review, 71(3), 75-86.

Moore, J. (2013). Shared Purpose: A Thousand Business Ecosystems, A Connected Community, and the Future. Mountain view: Create space publishing platform.

Nathan, M., \& Overman, H. (2013). Agglomeration, clusters, and industrial policy. Oxford Review of Economic Policy, 29(2), 383-404. https://doi. org/10.1093/oxrep/grt019

Neergaard, H., \& Ulhøi, J. P. (Eds.). (2007). Handbook of Qualitative Research Methods in Entrepreneurship. Cheltenham, UK; Northampton, MA: Edward Elgar. https://doi.org/10.4337/9781847204387

Neffke, F., Hartog, M., Boschma, R., \& Henning, M. (2018). Agents of structural change: The role of firms and entrepreneurs in regional diversification. Economic Geography, 94(1), 23-48. https://doi.org/10.1080/00130095. 2017.1391691

Obadić, A. (2013). Specificities of EU cluster policies. Journal of Enterprising Communities: People and Places in the Global Economy, 7(1), 23-35. https://doi.org/10.1108/17506201311315581

Parisot, X. (2013). Metaphor in organizational theory, the business ecosystem case. In Volume 22th AIMS International Conference. Clermont-Ferrand, France.

Penrose, E. T. (1952). Biological analogies in the theory of the firm. The American Economic Review, 42(5), 804-819. 
Pike, A., Rodríguez-Pose, A., \& Tomaney, J. (2017). Shifting horizons in local and regional development. Regional Studies, 51(1), 46-57. https://doi.or g/10.1080/00343404.2016.1158802

Piperopoulos, P. G. (2016). Entrepreneurship, Innovation and Business Clusters. London: Routledge. https://doi.org/10.4324/9781315579948

Pitelis, C. (2012). Clusters, entrepreneurial ecosystem co-creation, and appropriability: A conceptual framework. Industrial and Corporate Change, 21(6), 1359-1388. https://doi.org/10.1093/icc/dts008

Porter, M. (1998). Clusters and the new economics of competition. Harvard Business Review, 76(6), 77-90.

Porter, M. (2000). Location, competition, and economic development: Local clusters in a global economy. Economic Development Quarterly, 14(1), 15-34. https://doi.org/10.1177/089124240001400105

Porter, M., \& Ketels, C. (2009). Clusters and industrial districts: Common roots, different perspectives. In G. Becattini, M. Bellandi, \& L. De Propris (eds.), A Handbook of Industrial Districts (pp. 172-183). Cheltenham: Edward Elgar Publishing.

Rapanos, V. T., \& Kaplanoglou, G. (2014). Governance, growth and the recent economic crisis: The case of Greece and Cyprus. Cyprus Economic Policy Review, 8(1), 3-34.

Reeves, M., Levin, S., \& Ueda, D. (2016). The biology of corporate survival. Harvard Business Review, 94(1), 2.

Rinkinen, S., \& Harmaakorpi, V. (2018). The business ecosystem concept in innovation policy context: Building a conceptual framework. Innovation: The European Journal of Social Science Research, 31(3), 333-349. https:// doi.org/10.1080/13511610.2017.1300089

Rodríguez-Pose, A. (2013). Do institutions matter for regional development? Regional Studies, 47(7), 1034-1047. https://doi.org/10.1080/00343404 .2012.748978

Rong, K., Lin, Y., Li, B., Burström, T., Butel, L., \& Yu, J. (2018). Business ecosystem research agenda: More dynamic, more embedded, and more internationalized. Asian Business \& Management, 17(3), 167-182. https://doi.org/10.1057/s41291-018-0038-6

Rosemann, M., \& vom Brocke, J. (2015). The six core elements of business process management. In J. vom Brocke \& M. Rosemann (Eds.), Handbook on Business Process Management 1: Introduction, Methods, and Information Systems (pp. 105-122). https://doi.org/10.1007/978-3-642-45100-3_5

Rosier, B. (1985). Croissance et Crise Capitalistes (2nd edition). Paris: Presses Universitaires de France - PUF.

Rothschild, M. (1990). Bionomics: The Inevitability of Capitalism. New York: H. Holt.

Roundy, P. T., \& Asllani, A. (2018). The themes of entrepreneurship discourse: A data analytics approach. Journal of Entrepreneurship, Management and Innovation, 14(3), 127-158. https://doi.org/10.7341/20181436 
Sako, M. (2018). Business ecosystems: How do they matter for innovation? Communications of the ACM, 61(4), 20-22. https://doi. org $/ 10.1145 / 3185780$

Sayer, A. (1989). Postfordism in question. International Journal of Urban and Regional Research, 13(4), 666-695. https://doi. org/10.1111/j.1468-2427.1989.tb00141.x

Schaltegger, S., Lüdeke-Freund, F., \& Hansen, E. G. (2016). Business models for sustainability: A co-evolutionary analysis of sustainable entrepreneurship, innovation, and transformation. Organization \& Environment, 29(3), 264-289. https://doi.org/10.1177/1086026616633272

Schumpeter, J. (1939). Business cycles: A theoretical, historical, and statistical analysis of the capitalist process. New York: McGraw-Hill.

Schumpeter, J. (1942). Capitalism, Socialism, and Democracy. New York; London: Harper \& Brothers.

Scott, A., \& Paul, A. S. (1990). Collective order and economic coordination in industrial agglomerations: The technopoles of southern California. Environment and Planning C: Government and Policy, 8(2), 179-193. https://doi.org/10.1068/c080179

Scott, A., \& Storper, M. (2003). Regions, globalization, development. Regional Studies, 37(6-7), 579-593. https://doi.org/10.1080/0034340032000108697a

Shields, P. M., \& Rangarajan, N. (2013). A Playbook for Research Methods: Integrating Conceptual Frameworks and Project Management. Stillwater, OK: New Forum Press.

Simatupang, T. M., Schwab, A., \& Lantu, D. C. (2015). Building sustainable entrepreneurship ecosystems, International Journal of Entrepreneurship and Small Business, 26(4), 389-398. https://doi.org/10.2139/ssrn.3161598

Stebbins, R. A. (2001). Exploratory Research in the Social Sciences. Thousand Oaks, Calif: Sage Publications. https://doi.org/10.4135/9781412984249

Storey, D. J. (2016). Entrepreneurship and New Firm: Theory and Policy. London: Routledge. https://doi.org/10.4324/9781315544502

Storper, M., \& Scott, A. (1989). The geographical foundations and social regulation of flexible production complexes. In J. Wolch, The Power of Geography (RLE Social \& Cultural Geography): How Territory Shapes Social Life. London; New York: Routledge.

Stuck, J., Broekel, T., \& Diez, J. R. (2016). Network structures in regional innovation systems. European Planning Studies, 24(3), 423-442. https:// doi.org/10.1080/09654313.2015.1074984

Uyarra, E., \& Flanagan, K. (2010). From regional systems of innovation to regions as innovation policy spaces. Environment and Planning $C$ : Government and Policy, 28(4), 681-695. https://doi.org/10.1068/c0961

Valkokari, K. (2015). Business, innovation, and knowledge ecosystems: How they differ and how to survive and thrive within them. Technology Innovation Management Review, 5(8), 17-24.

Valkokari, K., \& Ketonen-Oksi, S. (2018). Understanding platforms and ecosystems as structures for value co-creation (p. 14). Presented at the 
ISPIM Innovation Conference - Innovation, The Name of The Game, Stockholm, Sweden. https://doi.org/10.22215/timreview/919

Veltz, P. (2014). Mondialisation, Villes Et Territoires: L'économie D'archipel (2nd edition). Paris: PUF. https://doi.org/10.3917/puf.velt.2014.01

Vlados, C. (2004). La Dynamique du Triangle Stratégie, Technologie et Managemen : I'Insertion des Entreprises Grecques dans la Globalisation. Thèse. Paris 10.

Vlados, C. (2005). The insertion of Greek firms into globalization: The dynamics of the triangle of strategy, technology and management. In Managing Global Trends and Challenges in a Turbulent Economy, University of the Aegean, Department of Business Administration. https://doi.org/10.2139/ssrn.3218009

Vlados, C. (2012). The search of competitiveness and the entrepreneurial evolution in a global environment: Toward a new approach of development dynamics based on the case of Greek productive system. Journal of Management Sciences and Regional Development, (8), 91116. https://doi.org/10.2139/ssrn.3218008

Vlados, C., Deniozos, N., \& Chatzinikolaou, D. (2018). Towards a new approach of local development under crisis conditions: Empowering the local business ecosystems in Greece, by adopting a new local development policy. International Journal of Regional Development, 5(1), 1-24. https://doi.org/10.5296/ijrd.v5i1.11955

Vlados, C., Deniozos, N., Chatzinikolaou, D., \& Demertzis, M. (2018). Towards an evolutionary understanding of the current global socio-economic crisis and eestructuring: From a conjunctural to a structural and evolutionary perspective. Research in World Economy, 9(1), 15-33. https://doi. org/10.5430/rwe.v9n1p15

Weber, M., \& Hine, M. (2015). Who inhabits a business ecosystem? The technospecies as a unifying concept. Technology Innovation Management Review, 5(5), 31-44. https://doi.org/10.22215/timreview/896

Wei, Y. D. (2015). Spatiality of regional inequality. Applied Geography, 61, 1-10. https://doi.org/10.1016/j.apgeog.2015.03.013

Williamson, P. J., \& Meyer, A. D. (2012). Ecosystem advantage: How to successfully harness the power of partners. California Management Review, 55(1), 24-46. https://doi.org/10.1525/cmr.2012.55.1.24

Witt, U. (2006). Evolutionary concepts in economics and biology. Journal of Evolutionary Economics, 16(5), 473-476. https://doi.org/10.1007/ s00191-006-0034-4

Wulf, A., \& Butel, L. (2017). Knowledge sharing and collaborative relationships in business ecosystems and networks: A definition and a demarcation. Industrial Management \& Data Systems, 117(7), 1407-1425. https://doi. org/10.1108/IMDS-09-2016-0408

Zahra, S. A., \& Nambisan, S. (2012). Entrepreneurship and strategic thinking in business ecosystems. Business Horizons, 55(3), 219-229. https://doi. org/10.1016/j.bushor.2011.12.004 


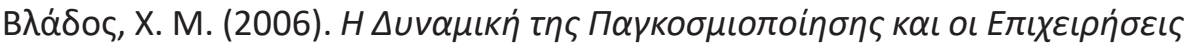

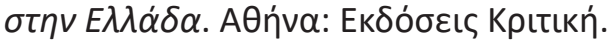

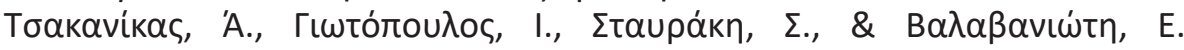

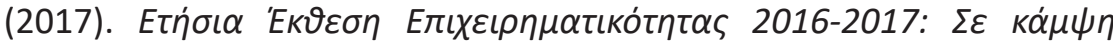

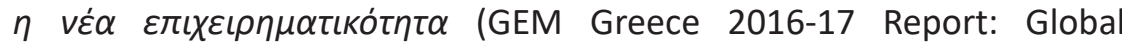
Entrepreneurship Monitor). Athens: Foundation for Economic \& Industrial Research.

\begin{abstract}
Abstrakt
W obecnym stanie restrukturyzacji globalizacji liczne badania badajq strategie na rzecz wzmocnienia lokalnej przedsiębiorczości i systemów produkcyjnych pod względem klastrów i ekosystemów. W tym artykule stosujemy i rozszerzamy podejście Stra. Tech.Man do dynamiki przedsiębiorczości jako alternatywnej podstawy formułowania polityki rozwoju ekosystemów biznesowych. Badajqc przypadek regionu Wschodniej Macedonii i Tracji, jednego z mniej rozwiniętych regionów w Grecji, stwierdzamy, że istniejq możliwości wykorzystania podejścia Stra.Tech.Man do nadruku, zapisu i, co za tym idzie, możliwości wzmocnienia strategicznego, technologicznego i zarzadczego zdolności „komórek” określonych ekosystemów biznesowych. W tym kontekście celem niniejszego opracowania jest nakreślenie nowego możliwego kierunku planowania i wdrażania polityki, w celu rozszerzenia innowacyjnych i konkurencyjnych kompetencji lokalnych ekosystemów biznesowych, zwłaszcza w kontekście słabiej rozwiniętego regionu, dzięki wykorzystaniu mechanizm ILDI (Institutes of Local Development and Innovation). W tym kierunku przedstawiamy „wstępne” i jakościowe badania terenowe, które przeprowadziliśmy w regionie Wschodniej Macedonii i Tracji, na próbie MŚP, w kategoriach diagnostycznych fizjologii Stra.Tech.Man.
\end{abstract}

Słowa kluczowe: polityka ekosystem biznesowy, klastry, fizjologia Stra.Tech.Man, mała i średnia przedsiębiorczość, region Wschodniej Macedonii i Tracji, dynamika globalizacji

\title{
Biographical notes
}

Charis Vlados holds a Ph.D. degree with a "Very Honorable Distinction" for his thesis on the types/forms of evolutionary integration of the enterprises operating in Greece into globalization that took place within the framework of the Research and Studies Center on Multinational Enterprises (C.E.R.E.M) of the "Paris X-Nanterre" University. The author's primary focus is on the fields of corporate strategy, competitiveness, entrepreneurship, economic policy, and globalization, while he has established and developed the "Stra.Tech. Man approach" in the field of business dynamics. Charis Vlados has been working with various research institutes and as a business consultant, both in Greece and abroad, for approximately twenty years. He is now a lecturer (academic tenure) with the Department of Economics of the Democritus University of Thrace in the scientific field of "International Economic Relations and Entrepreneurship," while has also taught in the past at the Universities 
of the Aegean and Peloponnese, and at various Public and Private Centers of Studies. Charis Vlados has authored until now seven scientific textbooks and monographs (in Greek) and more than 50 scientific publications in peerreviewed scientific journals and conference proceedings.

Dimos Chatzinikolaou holds an M.Sc. diploma from the Postgraduate Courses in "South-Eastern Europe Studies (specialization in Economics)" from the Department of Law of Democritus University of Thrace with degree excellent (10/10). Dimos Chatzinikolaou is now a Ph.D. Candidate with the Department of Economics of the Democritus University of Thrace at the field of "competitiveness, business ecosystems, and industrial policy." He is the co-author in more than twenty scientific articles in peer-reviewed scientific journals and conference proceedings, while his main areas of research include, among others, the fields of globalization, competitiveness, economic policy, and entrepreneurship. 